\title{
Neolithic flint mines of Treviño (Basque-Cantabrian Basin, Western Pyrenees, Spain)
}

\author{
Antonio Tarriño, Irantzu Elorrieta, Maite García-Rojas, Iñigo Orue, \\ Aitor Sánchez \\ Universidad del País Vasco / Euskal Herriko Univertsitatea (UPV/EHU), Vitoria-Gasteiz, Spain. \\ Email: Tarriño: antonio.tarrinno@gmail.com; Elorrieta: i_elobai@hotmail.com; \\ García-Rojas: maitensx@hotmail.com; Orue: innigo.orue@gmail.com; Sánchez: aitor.sanchezl@ehu.es
}

\begin{abstract}
:
The prehistoric Treviño flint mine complex is located in the Sierra de Araico-Cucho (Berantevilla, Alava - Condado de Treviño, Burgos), inside the lacustrine-palustrine Cenozoic (Aquitanian, Miocene) materials of the South-Pyrenean syncline of the Basque-Cantabrian Basin. It is a landscape unit constituted by a set of carbonated layers with abundant nodular and stratiform silicifications. The extraction mining works (often referred to as 'tailing') are usually identified as dumps or trenches, subtly visible and associated with archaeological materials.

An archaeological excavation was carried out in one potential mining structure (dump or pit) that was detected by LiDAR (Light Detection and Ranging) in the mountain pass of "Pozarrate" near the villages of Grandival and Araico (Treviño, Burgos). In this work we present the results of the excavation of the last two years. The existence of a Neolithic mining dump (the tailings) with a chronology ca. $5000 \mathrm{cal}$. BC was confirmed. The base rock level with nodular flint was reached and the impressions of the exploited nodules have been identified. As well, the extraction front which reaches about 4.0-5.0 metres in height was delimited. Thousands of lithic remains associated with the extraction and the initial processing (shaping) of flint were collected, as along with mining tools. We have found and described three types of mining structures: trenches, linear dumps and crescent-shaped (or "half-moon-shaped") dumps.

This site is one of the few prehistoric flint mines dated in the Iberian Peninsula. Recent investigations in the Cantabrian Mountains and Western Pyrenees indicate that the circulation and use of Treviño flint during Prehistory reached many Holocene and Pleistocene archaeological sites, located hundreds of kilometres away from the outcrops.
\end{abstract}

Keywords: Neolithic; mines; raw materials; flint; mineral resources; prehistory; Treviño; Western Pyrenees

\section{Resumen:}

El complejo prehistórico minero de sílex de Treviño se sitúa en la Sierra de Araico-Cucho (Berantevilla, Alava - Condado de Treviño, Burgos), en materiales lacustres-palustres del Cenozoico (Aquitaniense, Mioceno) en el Sinclinal Surpirenaico de la Cuenca Vasco-Cantábrica. Se trata de una

Published by the School of History, Classics and Archaeology, University of Edinburgh ISSN: 2055-0472. URL: http://journals.ed.ac.uk/lithicstudies/

This work is licensed under a Creative Commons Attribution 2.5 UK: Scotland License. 
unidad constituida por un conjunto de niveles carbonatados con presencia de abundantes silicificaciones nodulares y estratiformes. Habitualmente se identifican labores mineras de extracción como escombreras o zanjas sutilmente visibles y asociadas a materiales arqueológicos.

Se ha llevado a cabo una excavación arqueológica en una estructura minera potencial (escombrera o pozo) que fue detectada por LiDAR (Light Detection and Ranging) en el collado de Pozarrate cerca de los pueblos de Grandival y Araico (Treviño, Burgos). En este trabajo presentamos los resultados de los dos últimos años de excavación. Se ha confirmado la existencia de una escombrera neolítica de unos $5000 \mathrm{AC}$ años de antigüedad. Se ha alcanzado el nivel de base con sílex nodular y las impresiones de los nódulos explotados han sido identificados. También se ha delimitado el frente de explotación que alcanzará los 4,0 - 5,0 metros de altura. Se han recogido miles de restos líticos asociados a los trabajos de extracción y conformación inicial, así como herramientas mineras. Hemos detectado y descrito tres tipos de estructuras mineras: zanjas, escombreras lineales y escombreras de media luna.

Este yacimiento es una de las pocas minas prehistóricas datadas en la Península ibérica. Investigaciones recientes indican que en la Cordillera Cantábrica y Pirineo occidental la circulación y uso del sílex de Treviño llega a numerosos yacimientos arqueológicos del Holoceno y del Pleistoceno, situados incluso a centenares de kilómetros de los afloramientos.

Palabras clave: Neolítico; minas; materias primas; sílex; recursos minerales; prehistoria; Treviño; Pirineo occidental

\section{Introduction}

The archaeological area of the Treviño flint mines is located in the Sierra de Araico Cucho in the Western Pyrenees (Burgos, Spain). This mountain range is a homoclinal structure that reaches 901 metres (at El Cerro peak), separating the basins of the rivers Ayuda and Rojo situated about 450-550 metres above sea level (Figure 1). The outcrops comprise a large area of about 2,000 hectares, where there is a wide variety of lacustrine-palustrine flint outcrops. It is a great site complex with countless vestiges associated with mining exploitation. These flints have been employed throughout prehistoric times as the study of Cantabrian-Pyrenean sites confirms (Tarriño et al. 2011b).

The results of the last excavation works carried out in 2012 and 2013 are presented in this paper. These works allowed for the defining of the structures and the flint exploitation methods. The excavation zone is specifically located in the mountain pass named "Pozarrate" near the villages of Grandival and Araico, with the following coordinates: $\mathrm{X}=517.975 ; \mathrm{Y}=$ 4.727.854; altitude = $814 \mathrm{~m}$ ASL (projection UTM ETRS89 Time Zone $30 \mathrm{~N}$ ). This place was selected because of the presumable existence of exploitation structures. The surface revealed many flint remains and tools that might have been employed for the mining activity at Araico.

The first archaeological intervention at the site dates back to the field surveys carried out by D. Estavillo during the 1930's. Estavillo collected more than 50 ophite quarry-hammers; most of them were complete, with different sizes and weights from 0.5 to $6.5 \mathrm{~kg}$, and with a central depression to make handling possible. He also collected flint cores which exhibited reuse marks, e.g., knapping hammerstones (Estavillo 1955). In the Archaeological Museum of Alava collection, there are currently more than a hundred boxes full of the lithic materials (Estavillo collection). As a consequence of this important legacy, in the beginning of the 1980 's a field survey project along the Rojo River valley was promoted. Thanks to this project many archaeological sites were found in the area around the flint outcrops. In the high part of the mountains, explorations were made in the area of "Alto de San Miguel" (Ortiz et al. 1990), where the excavation is currently located. 


\section{GEOGRAPHICAL SITUATION}

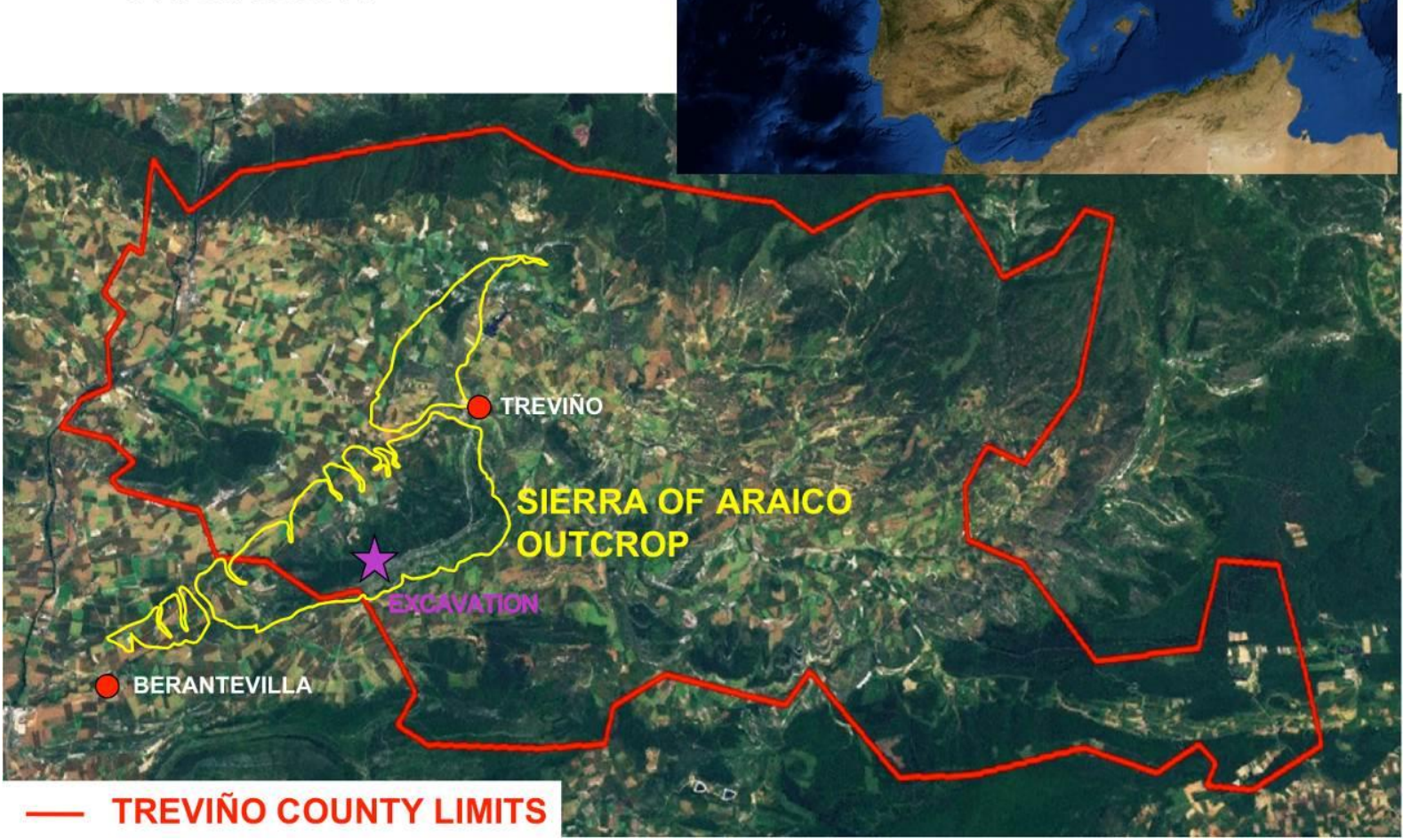

Figure 1. Localization of the outcrops of the carbonated unit that contain the flint and the spot where the excavation was performed.

In the year 2001, the $\mathrm{PhD}$ thesis of A. Tarriño (2001), produced from a geoarchaeological perspective, highlighted the presence in Araico and Cucho of relevant evidence of a large prehistoric mining complex with many trenches and dumps, as well as a vast quantity of flint lithic remains and ophite tools.

Eight years later, in 2009, at the "2nd International Conference of the UISPP Commission on Flint Mining in Pre-and Protohistoric Times" (Tarriño et al. 2011a), the results of the first research related to the mines were presented. Consequently, in 2010, the geomorphologic map of the site was published. On this map the erosive morphologies of the mining activity were represented based on the LiDAR data (Benito-Calvo et al. 2010). And two years later new field survey works were carried out, applying the data from the SPOT-5 satellite, as a method for the identification of structures. Due to this, the tailings that jointed the trenches described by LiDAR were recognized (Orue 2013).

\section{Hypothesis and methods}

The whole archaeological area presents a high density of archaeological surface material, together with the existence of abundant geological flint of excellent quality; both are evidence of mining activity. For this reason, it was necessary to locate and define the exploitation areas of this large outcrop which supplied the Cantabrian-Pyrenean Region.

The dense vegetation is one of the factors that obstructs the location and understanding of strip mining in the mountains; therefore a survey plan was designed using LiDAR data. The information was classified to generate a DTM (Digital Terrain Model) of the entire surface where flint crops out. Aerial photographs were also used, comparing them with the DTM 
results. The acquired data was provided by the Basque Government web site (www.geoeuskadi.net) and processed with ArcGIS 9.8 software.

The results of this data revealed erosive lines as trenches and mound formations which followed the layers of the terrain. A general interpretation would have been impossible without these methods, due to the dense vegetation and the integration with the landscape caused by the passing of time. Finally the survey confirmed that the trenches and dumps are associated with the presence of abundant flint remains (Figure 2).

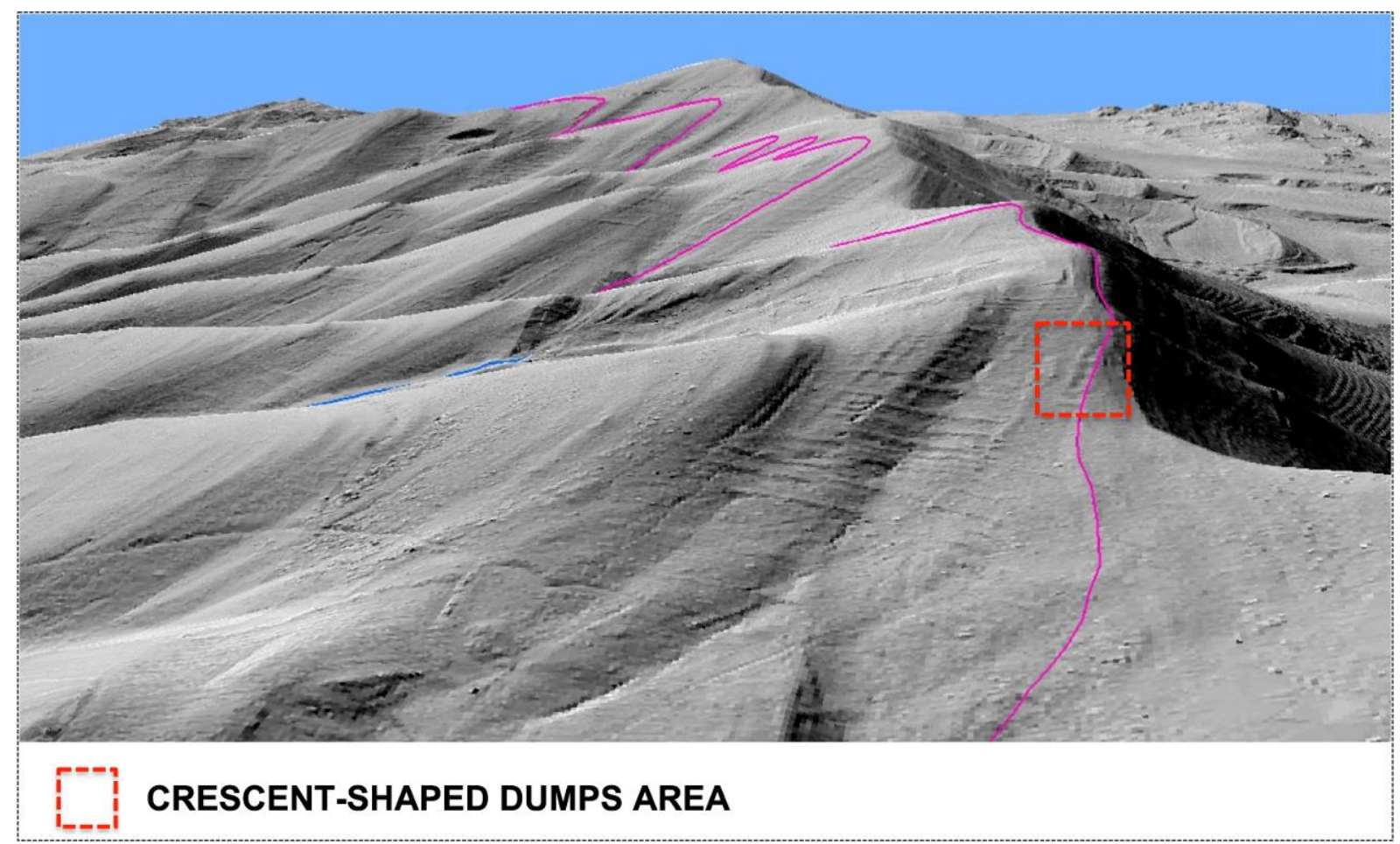

Figure 2. 3D Model of "Sierra de Araico" with the line of the nodular flint layer. The red square marks the location of the excavation with the crescent-shaped dumps.

\section{Exploited flint}

The silicifications are located in the unit defined by the geological map 1:50,000 (IGME, 1978) as "Marlstone and lacustrine limestones" of the Early-Middle Miocene (Aquitanian). The slopes of the A-126 road that connects Treviño (Burgos) to La Puebla de Arganzón (Burgos) allow a good observation of these materials.

These silicifications are well represented in the geological record but have remained unnoticed in geological studies. Ramírez del Pozo (1973:39) in his "Geological synthesis of Alava Province" mentioned the existence of this flint for the first time. These silicifications are situated inside a thick carbonate unit which outcrops in the South-Pyrenean syncline of Miranda-Treviño. Its thickness exceeds 1,000 metres fundamentally composed of lacustrine carbonates (IGME 1978). In this unit, compact limestone and dolomite, dolomitic limestone and calcareous dolomite with diverse cementation degrees are found (Figure 3). Some of these levels present little quantities of clay minerals and are rich in organic matter and they are often associated with silicifications (Tarriño 2001).

On the terrain we found many dark coloured flint nodules with a large content of organic material. Even when they are fractured, they give off a fetid odour because of the hydrocarbon volatilization. There are two types of nodules whose main characteristic is the cortex. The most common ones present cortex of between 2 and $5 \mathrm{~mm}$ thickness. Their colours are slightly darker (brown, dark grey) and, inside, they have small areas of unfinished 
silicification with hollow spaces and carbonate impurities. For this reason, these flints have little value for knapping. Also because of this, they appear in the site as rocky blocks that have been thrown out.

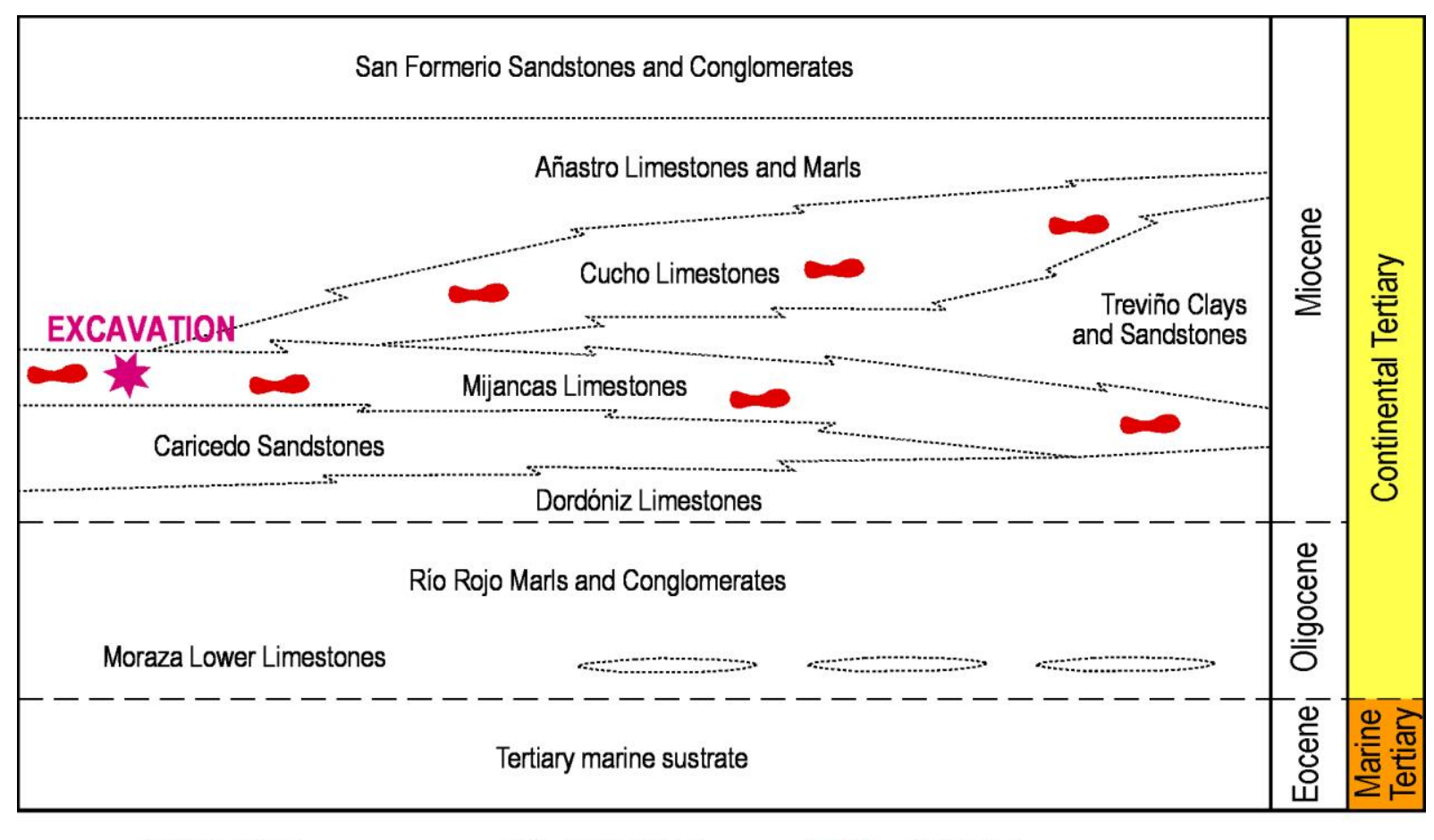

Figure 3. Lithostratigraphic scheme of the units with flint.
Figual contact

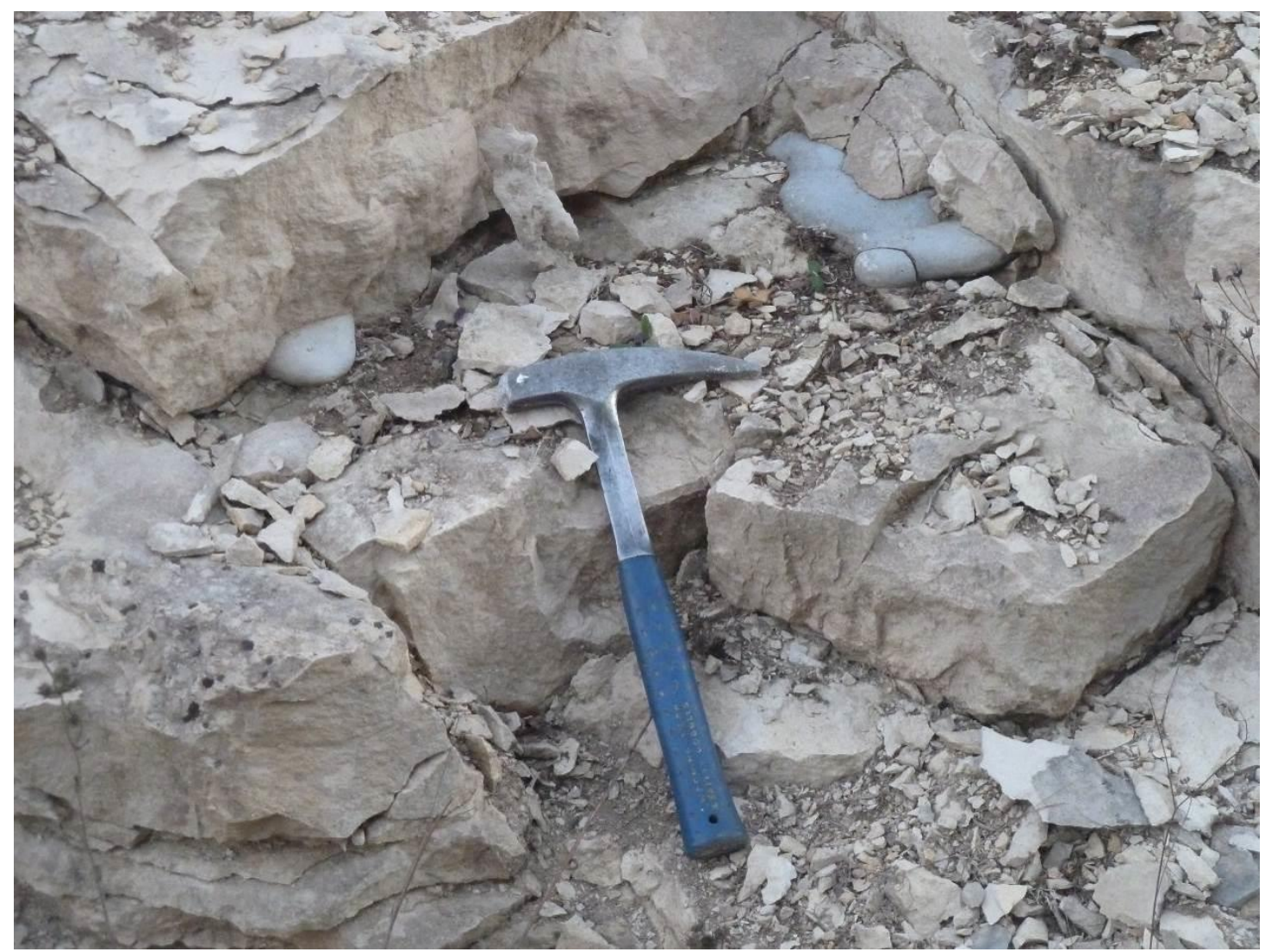

Figure 4. Outcrop of the nodular flints exploited at the mines, without cortex, included in the poorly consolidated lacustrine-palustrine limestones. 
The other variety, with best quality, presents a very thin cortex that appears bluish grey in colour when recently extracted (Figure 4). It is homogeneous with a very fine grain (microcrystalline - grains ranging from 2 to $50 \mu \mathrm{m}$ in diameter, and cryptocrystalline - grains being less than 1 or $2 \mu \mathrm{m}$ in diameter (Luedtke, 1992: 11)) and only minor carbonate impurities (Figures $5 \& 6$ ). (Crystalline nature is only vaguely revealed, even microscopically in thin section by transmitted polarized light.) The host rock is whitish lacustrine limestone with some dolomite, little cementation and plenty of ostracods. They are poorly consolidated carbonates which, combined with the presence of a very thin cortex, make the nodules easy to free. Thus, this contributes to the establishment of the mining extraction works on these silicifications during Prehistory.
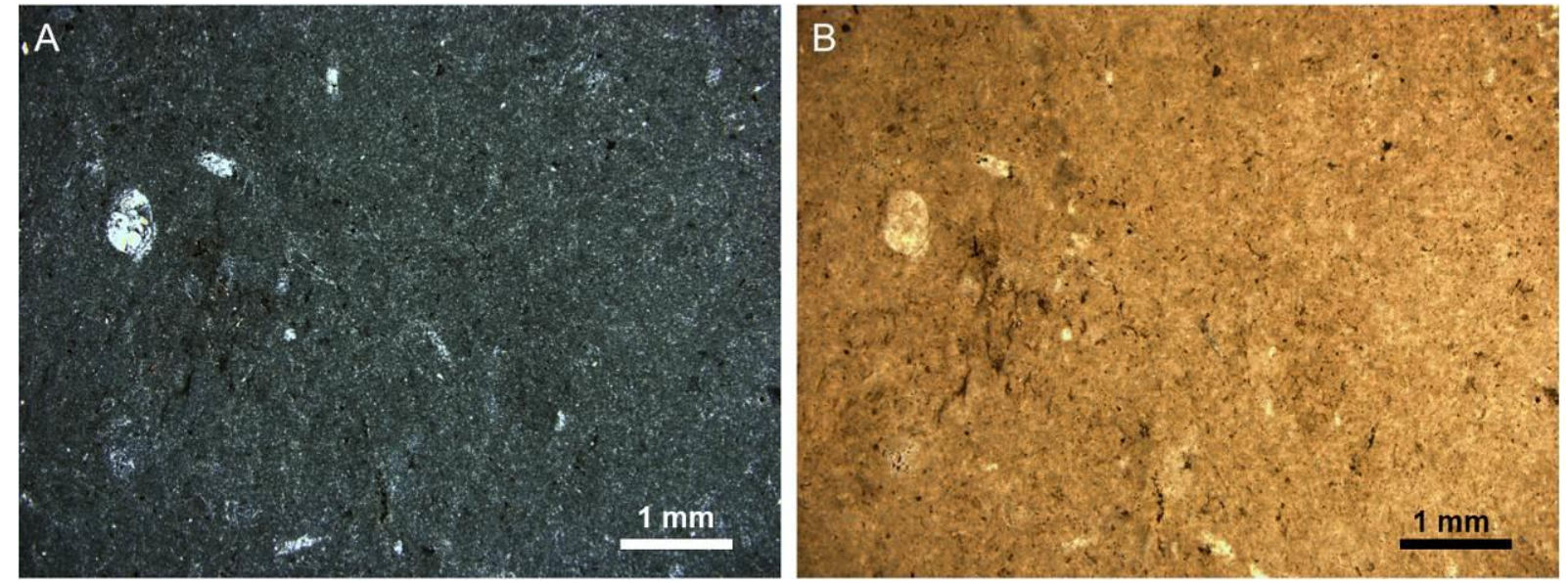

Figure 5. Microscopic appearance of the nodular flint (ARK-01SX). It presents a fine grained texture, microcryptocrystalline quartz with ostracods and low concentrations of organic matter. A. Crossed polarisers (xP); and B. the same view with one polariser (1P) (25x).

\section{Results}

As they are fundamentally silicifications with poorly consolidated host rocks, it can be deduced that the extraction of the blocks would not have been difficult. In this way extraction fronts (also referred to as the 'extraction faces') were created following the layers which penetrate the substratum. This preliminary hypothesis was fundamental for the surveys and the interpretation of the extraction methods in the mountains which have been developed in recent years.

\subsection{Geomorphological interpretation}

After studying the data, interpretation was made. In the excavation sector, three types of mining structures were observed: 1) trenches, 2) linear dumps and 3) crescent-shaped dumps (Figure 7). When the vegetation allows it, these mining works can be detected on the surface. Generally, surface features are associated with the mine dumps. Sometimes only the dumps can be identified but at other times only the trenches are discernible.

\subsubsection{Trenches}

When the layer crops out on the southern hillside, the most appropriate method of extracting the flint is the trench excavation. The trenches are observed as small linear depressions showing an erosive appearance that follow the direction of the layers (Figure 8). 


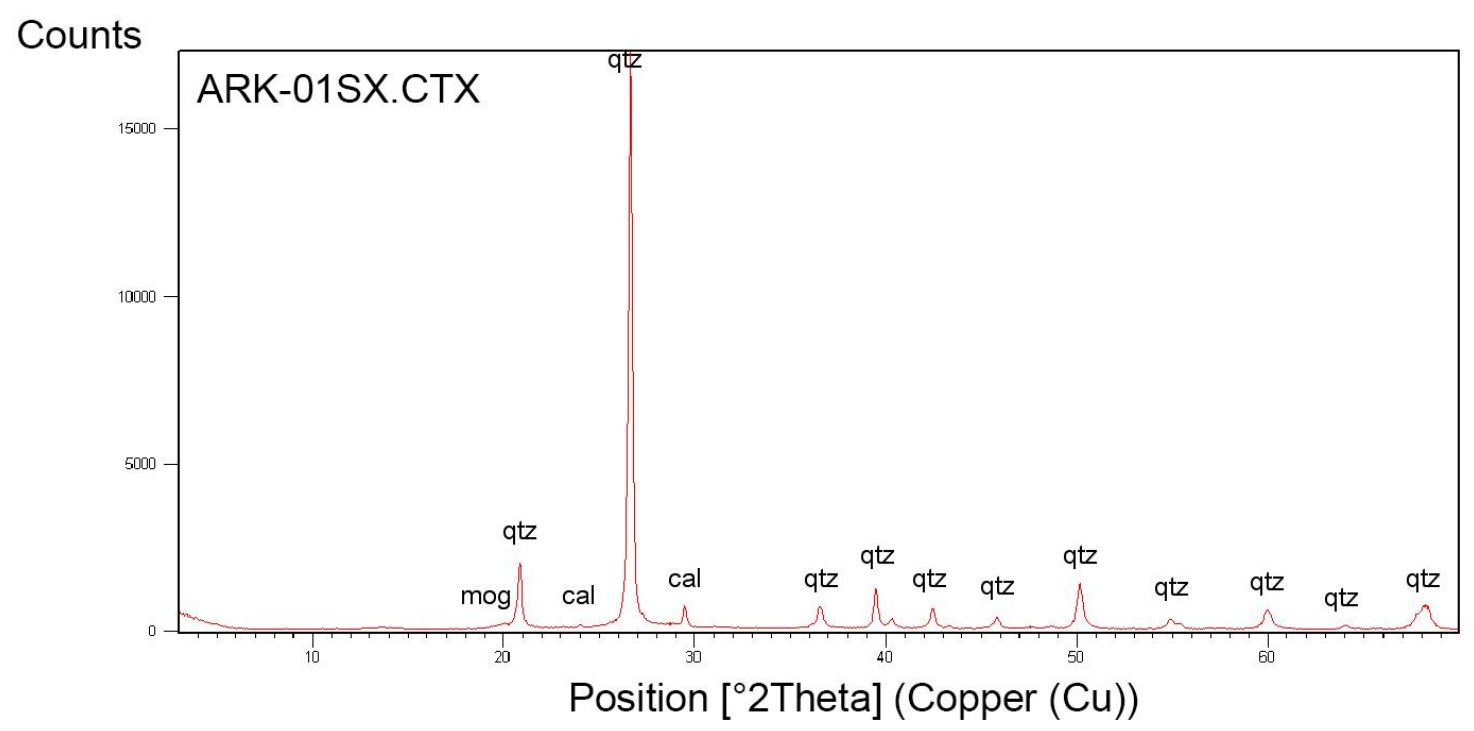

\section{Counts}

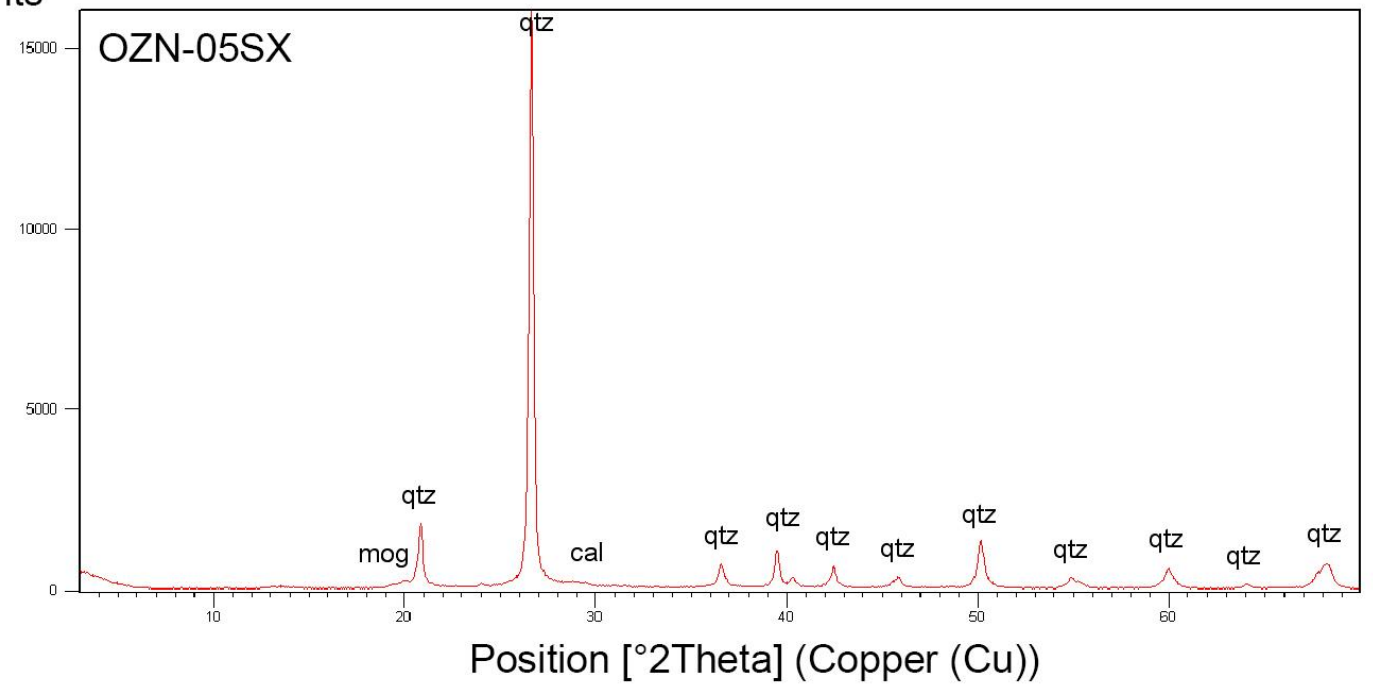

\section{Counts}

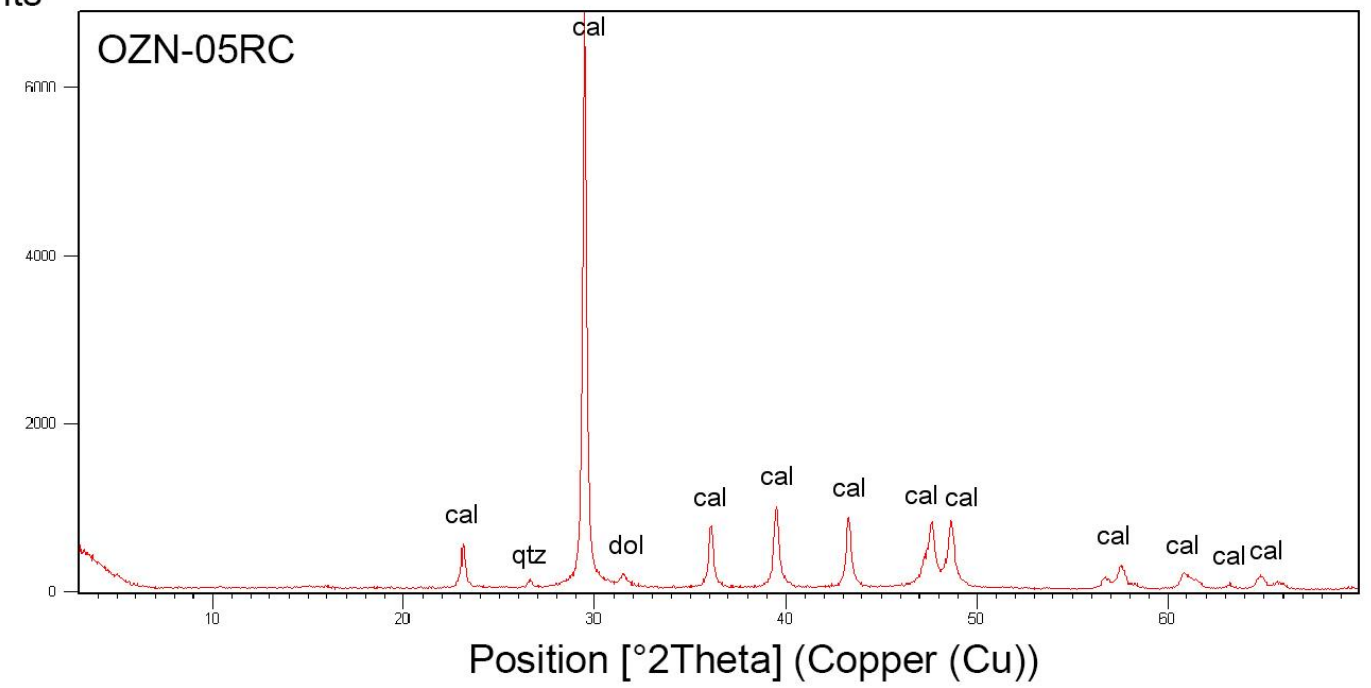

Figure 6. Diffractograms where the mineralogical composition of the nodular flint with cortex is observed (ARK-01SX.CTX). It contains carbonate impurities (calcite - cal) and moganite (mog) traces; flint without cortex (OZN-05SX) with few impurities and moganite (mog) traces; and, carbonate host rock (OZN-05RC) which is limestone (cal) with a small amount of dolomite (dol). 

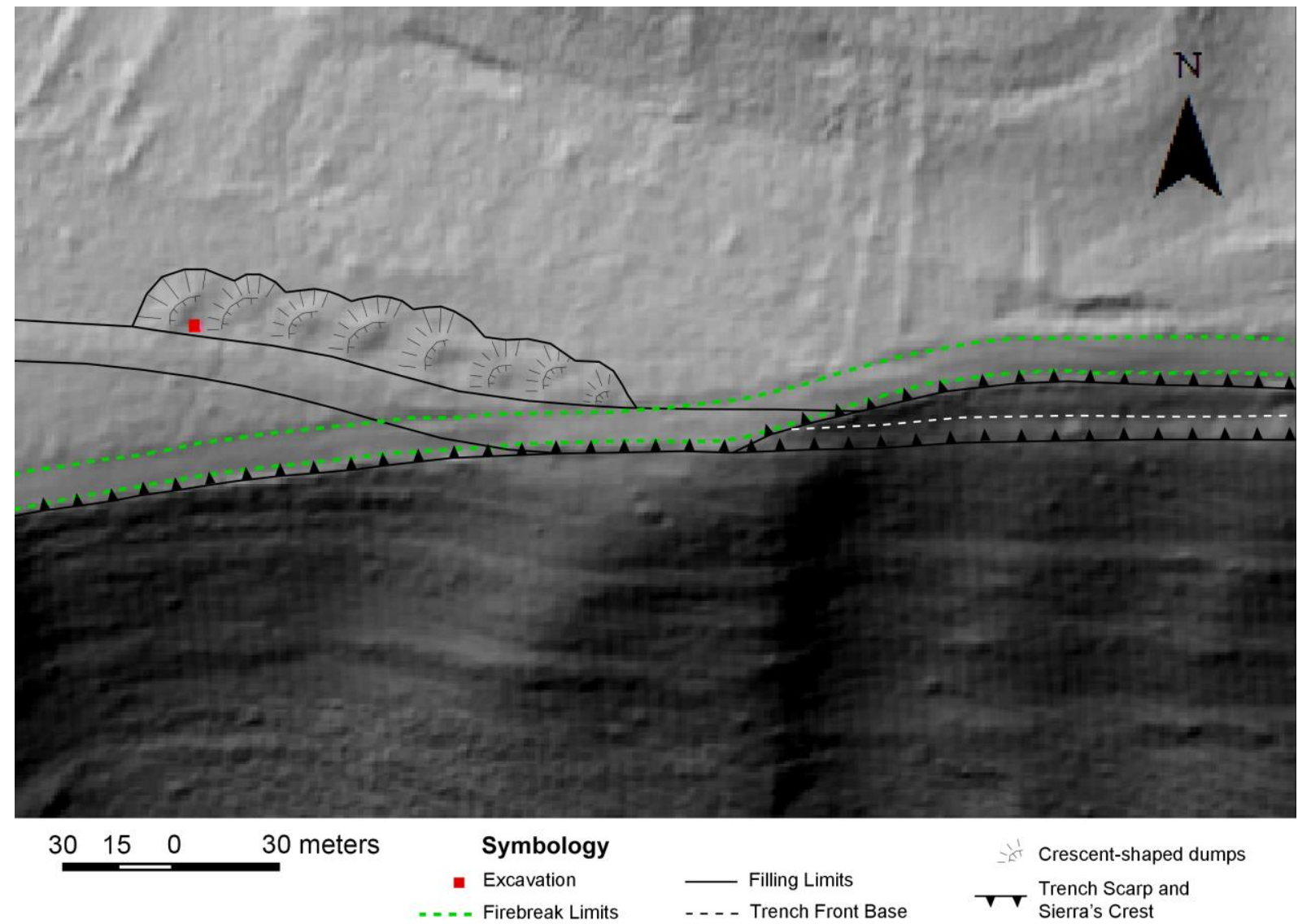

Figure 7. Geomorphological interpretation of mining structures in the excavation area.

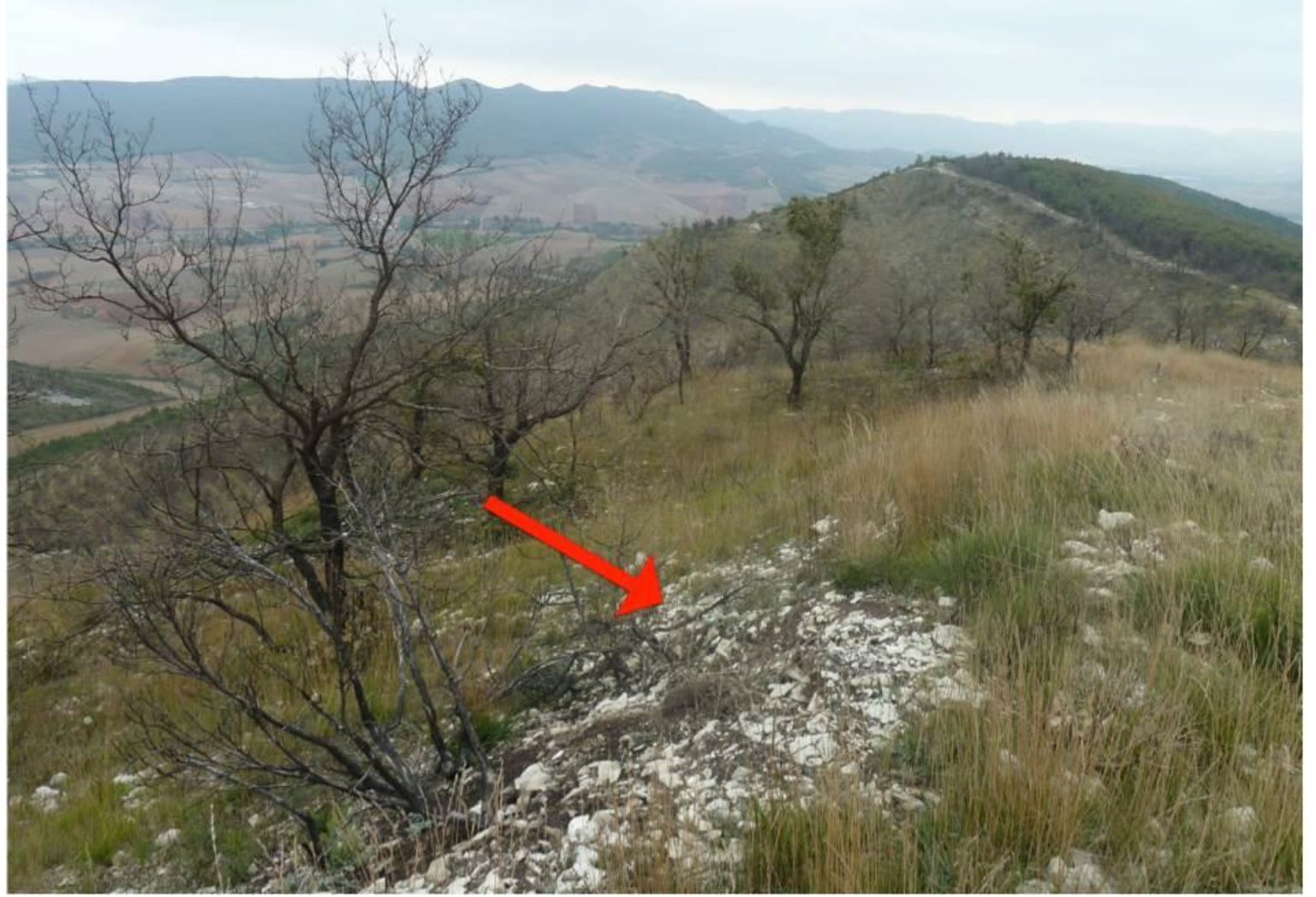

Figure 8. A view of the mining trench. 


\subsubsection{Linear dumps}

When the flint layers cross toward the northern side of the hill, the method of exploiting the flint has to change because the stratum crops out in the same direction of the slope. This fact is geomorphologically represented as linear dumps of about 12-15 metres wide and many thousands of metres long. It is estimated that the extraction front was about 2.0-2.5 metres height. They are part of the terrain, so they are practically impossible to be detected by photointerpretation (Figure 9).

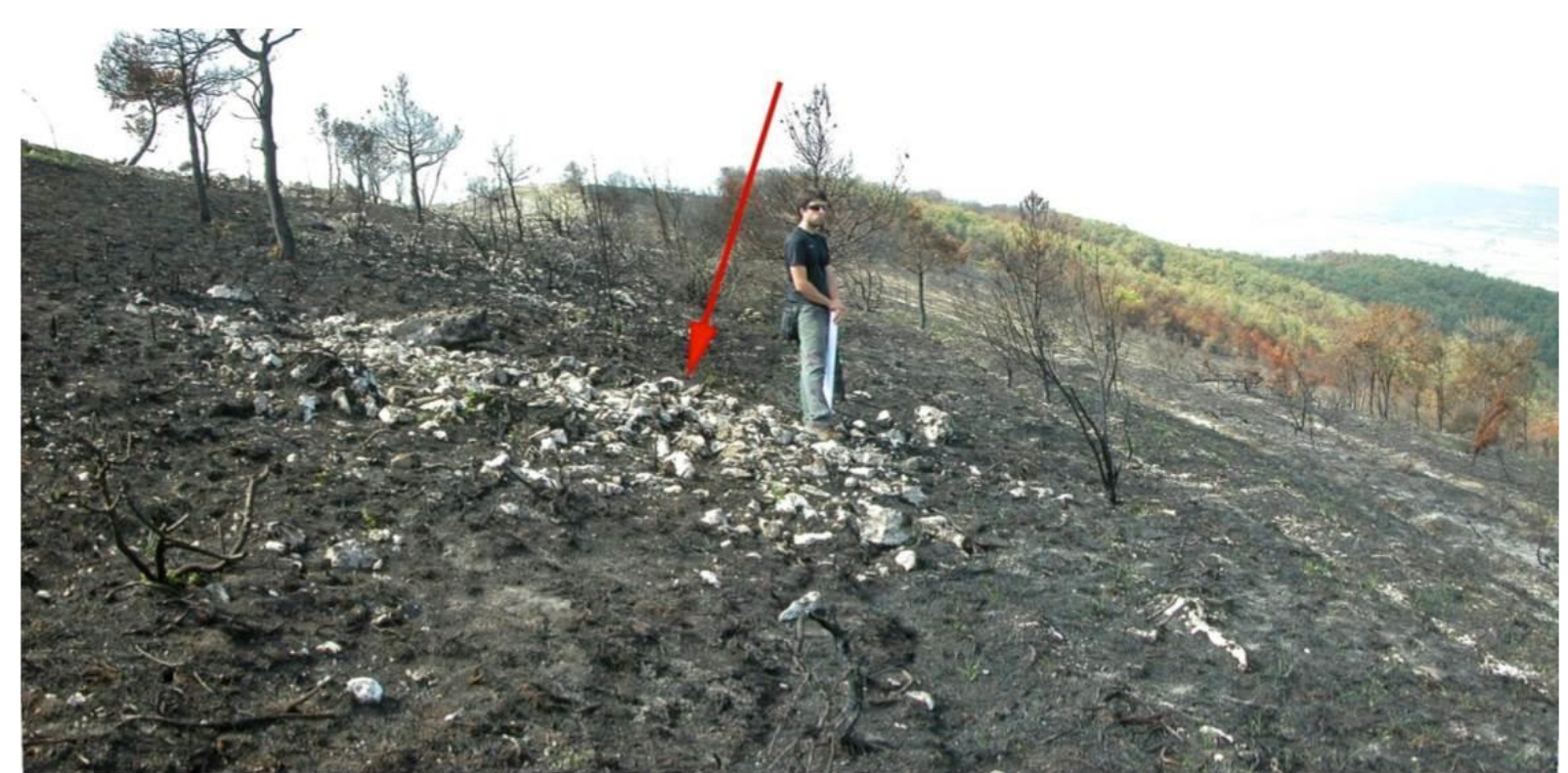

Figure 9. A view of a linear dump on the northern mountainside of "Sierra de Araico".

\subsubsection{Cresecent-shaped dumps}

At the highest part of the northern side of the mountain, where the excavation is located, the dump can be interpreted by means of the height and the dip of the flint stratum at its base. Due to its morphology, which is described below, we called this type of dump a 'crescentshaped dump'. The dump is double the width of the linear dump mentioned above, up to 2530 metres wide. In this area the existence of 8 dumps or depressions which continue to the crest until they turn into a trench has been confirmed. In these depressions the extraction fronts, due to their form, might reach 4.0-5.0 metres in height (Figure 10).

\subsection{Crescent-shaped dump excavation}

The intensive excavation of the crescent-shaped dump started in the year 2011. From the beginning, the aim was to delimit its extent, as well as to continue with its excavation to understand how this type of structure was managed. In this period of time, 10 square metres were excavated, four of them excavated in depth (Tarriño et al. 2011b). By 2012 the bedrock was reached and the excavation was broadened in order to delimit the dump through the digging of two trenches. In the same way, in 2013 the delimitation of this dump was continued by completing an extension in the form of an additional 14 square metres (Figure 11).

The mine dump excavated in 2011 and 2012 is 2.8 metres deep. Its stratigraphic section is generally formed by two levels. The first one presents a high number of clasts smaller than $10 \mathrm{~cm}$ and a few blocks between 20 and $30 \mathrm{~cm}$ while the second one is characterised by large blocks which may be over 0.5 metres, most of them presenting marks derived from mining 
activity (Figure 12). Under the blocks the rock base of the dump was identified. It coincided with the nodular flint level that the Neolithic miners were extracting, and the hollow depressions where the nodules were, as well as a piece of flint still on the rock can be observed (Figure 13).

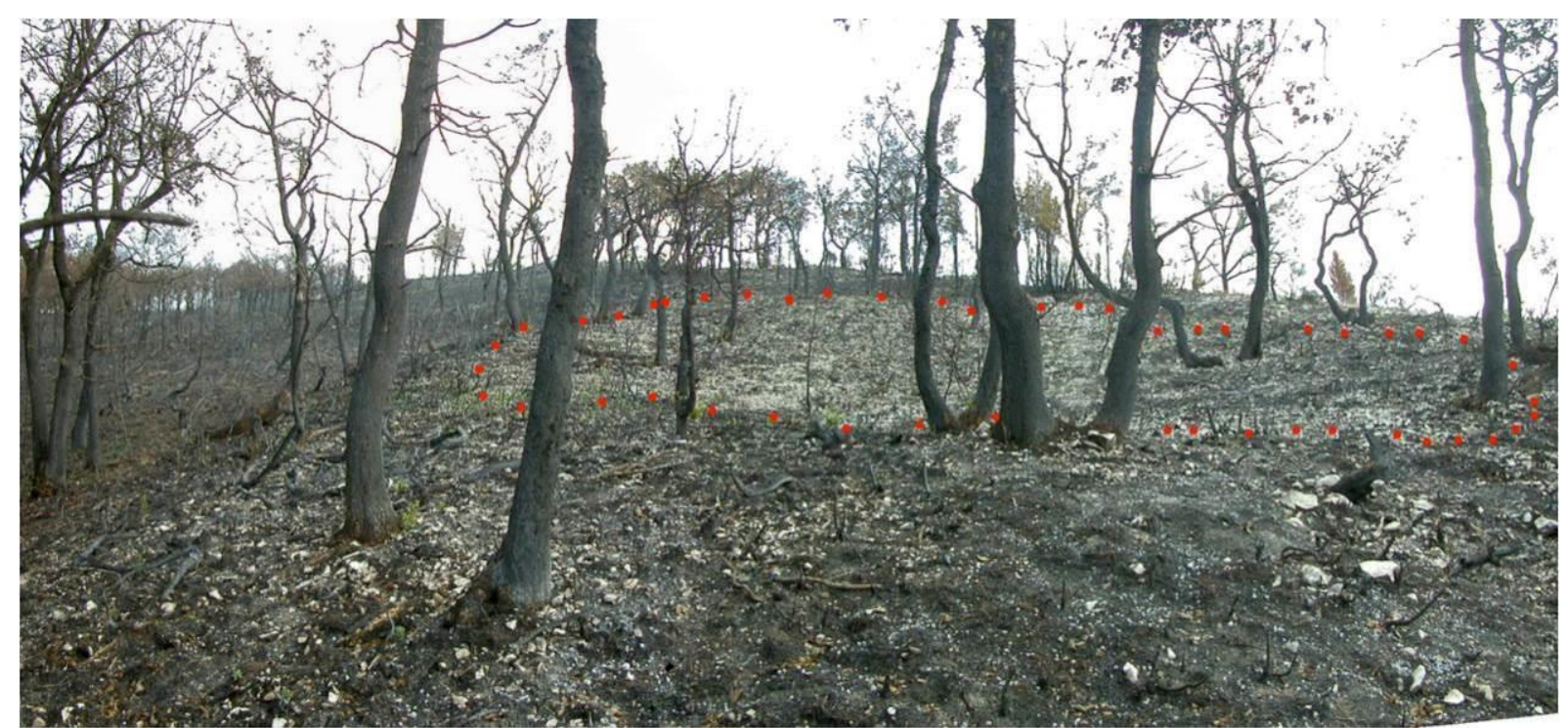

Figure 10. View of a crescent-shaped dump, showing the central depression before the excavation.

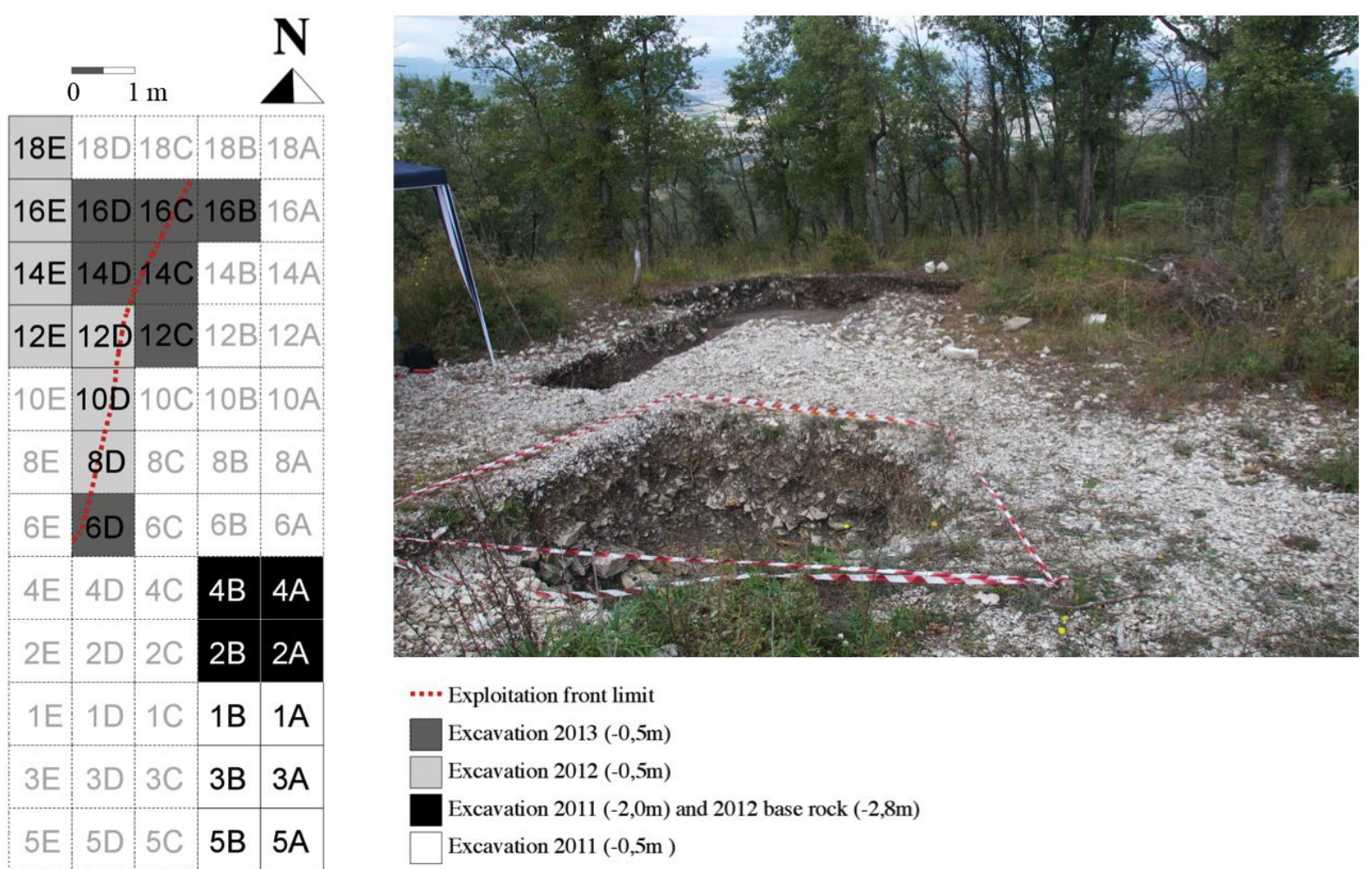

Figure 11. A plan view of the excavation and a photographic view of the site.

Once mining activity was confirmed and the layer of flint exploited by Neolithic miners identified, in 2012 we continued locating the quarry front. Two trenches were excavated, which are in the upper part of the same filling deposit of clasts and blocks mentioned above, whereas under this layer the original Neolithic slope appeared next to the edge of the crescent- 
shaped dump. Throughout 2013, the excavation work focused on the delimitation of the dump, and the effort in the end revealed the limit clearly (Figure 14).

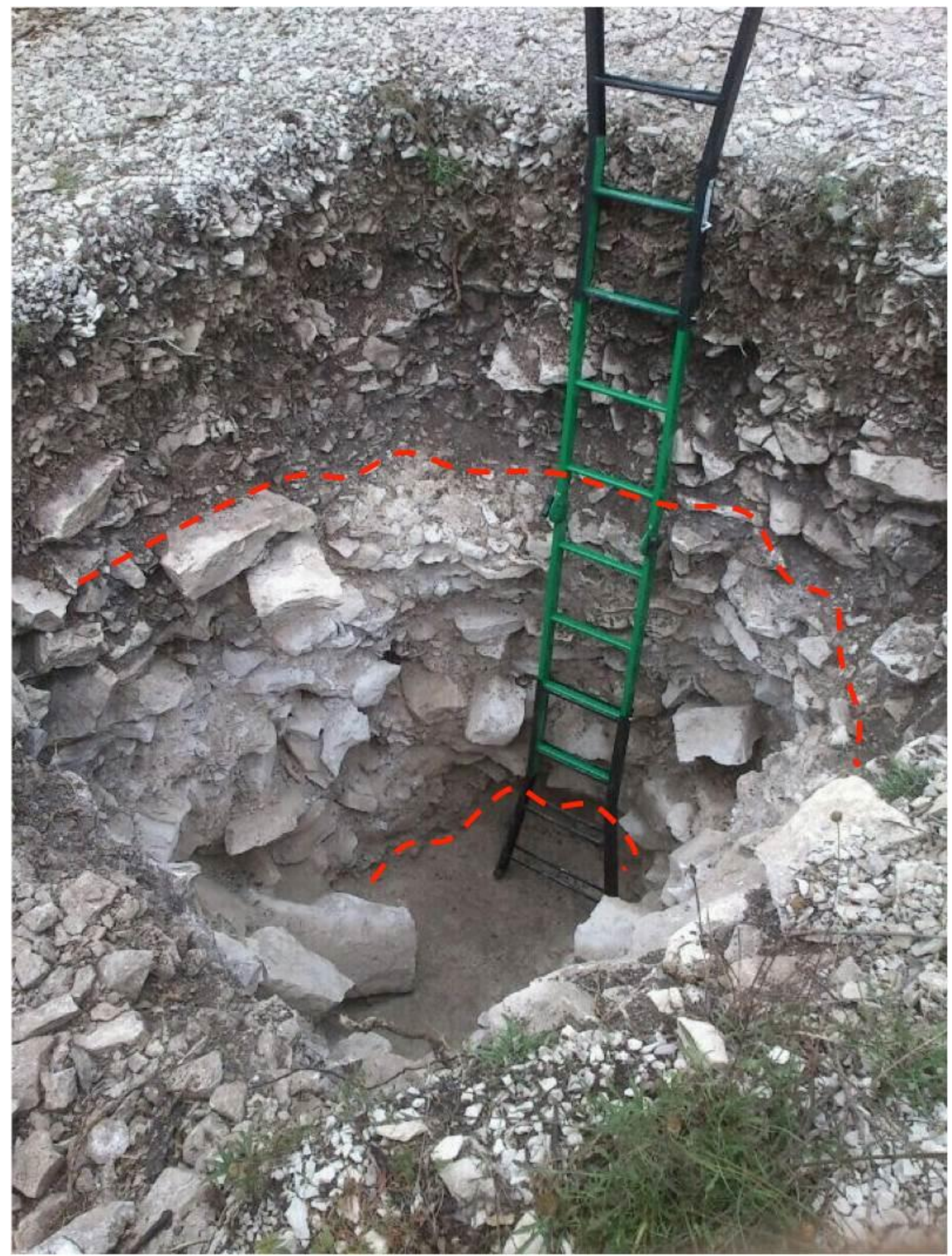

Figure 12. Photograph displaying the stratigraphy and the base rock of the crescent-shaped dump. 


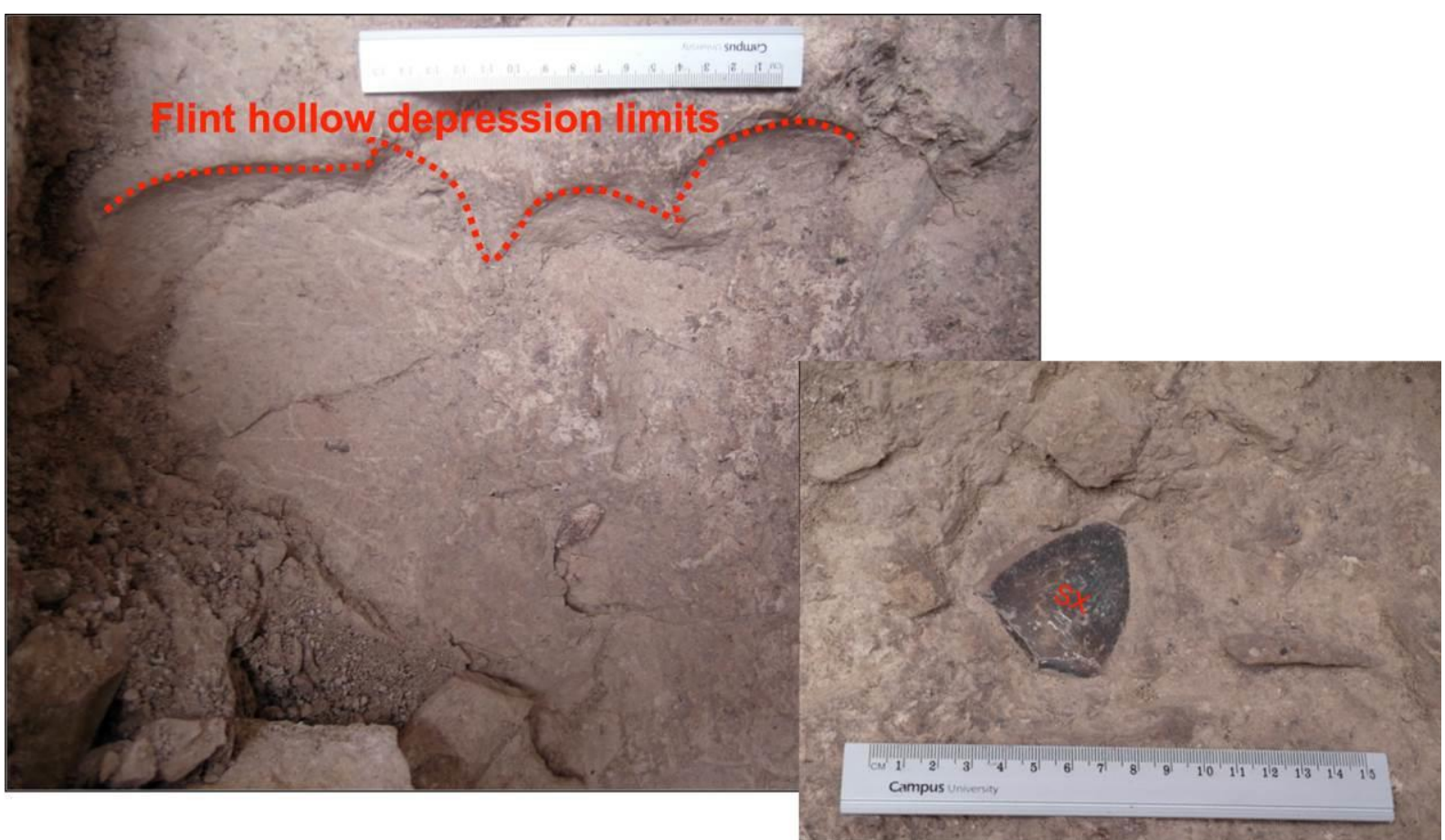

Figure 13. Left: Hollow depressions of the flint nodules after their extraction from the bedrock. Right: A piece of nodular flint still within the host rock.

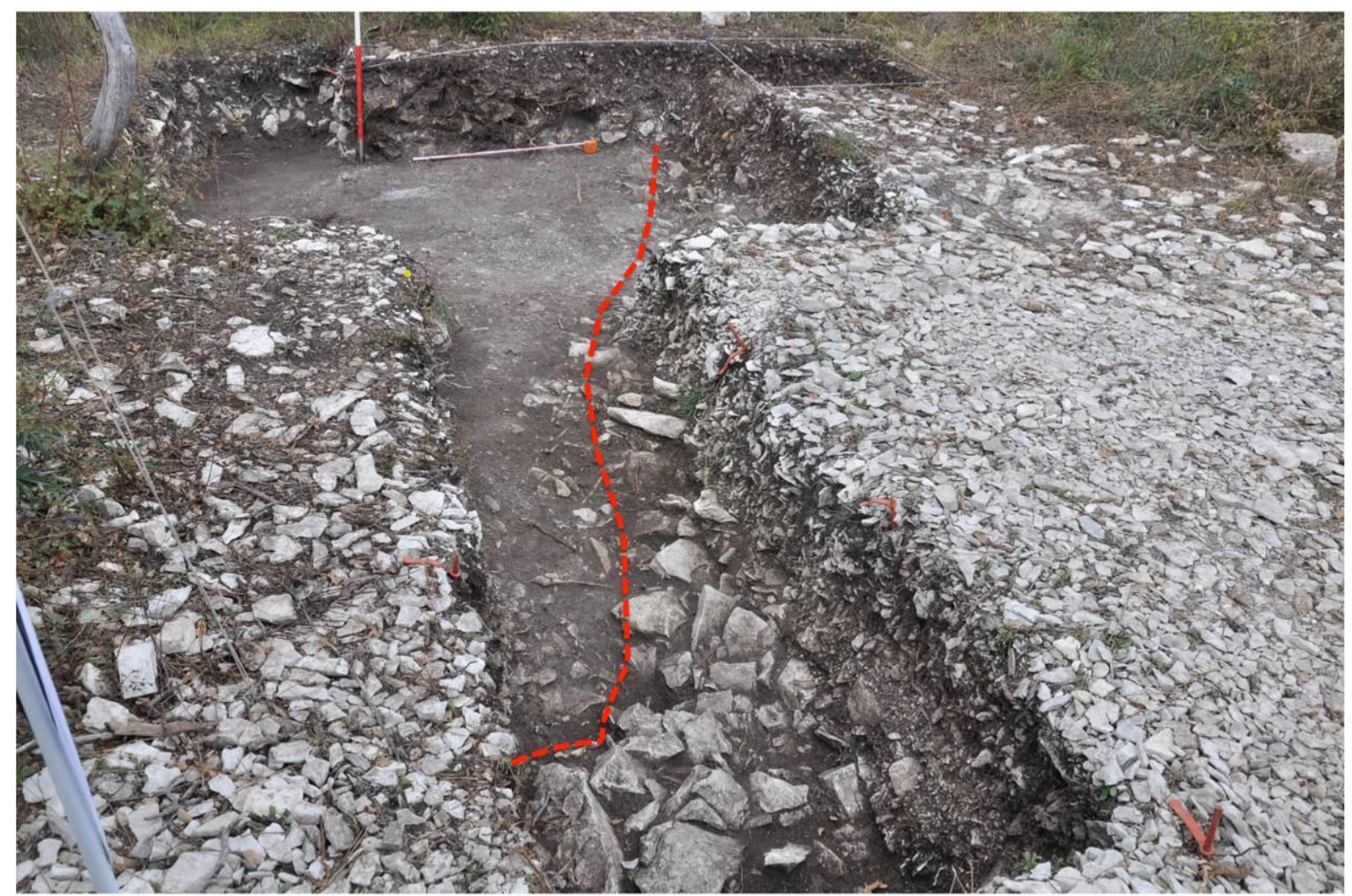

Figure 14. A photo showing the limit of the crescent-shaped dump after the 2013 excavation.

\subsection{Archaeological materials recovered}

The lithic assemblage recovered is composed of the remains of flint knapping, retouched artefacts, knapping hammerstones and general hammers (Tarriño et al. 2011b). The knapping remains are characterised by the presence of débitage products, cores, and tested flint nodules. 
Within the first group there are flakes and blades with dimensions of about ten centimetres, some being even longer. Generally they are thick and a high percentage have cortex on the dorsal surface. The striking platforms of these products are mainly doublefaceted and single-faceted of large size and they sweep away part of the percussion platform. In the same way, the bulbs of force are very marked. In terms of technical evidence that can be observed on the dorsal surfaces of these products, few negatives of previous extractions are detected, and those frequently have cortex surfaces. Together with the flaking products there are also core sharpenings which are characterised by one percussion platform and one flaking platform (Figure 15.1). The entire ensemble has deep negatives of large size from previous flake removals.

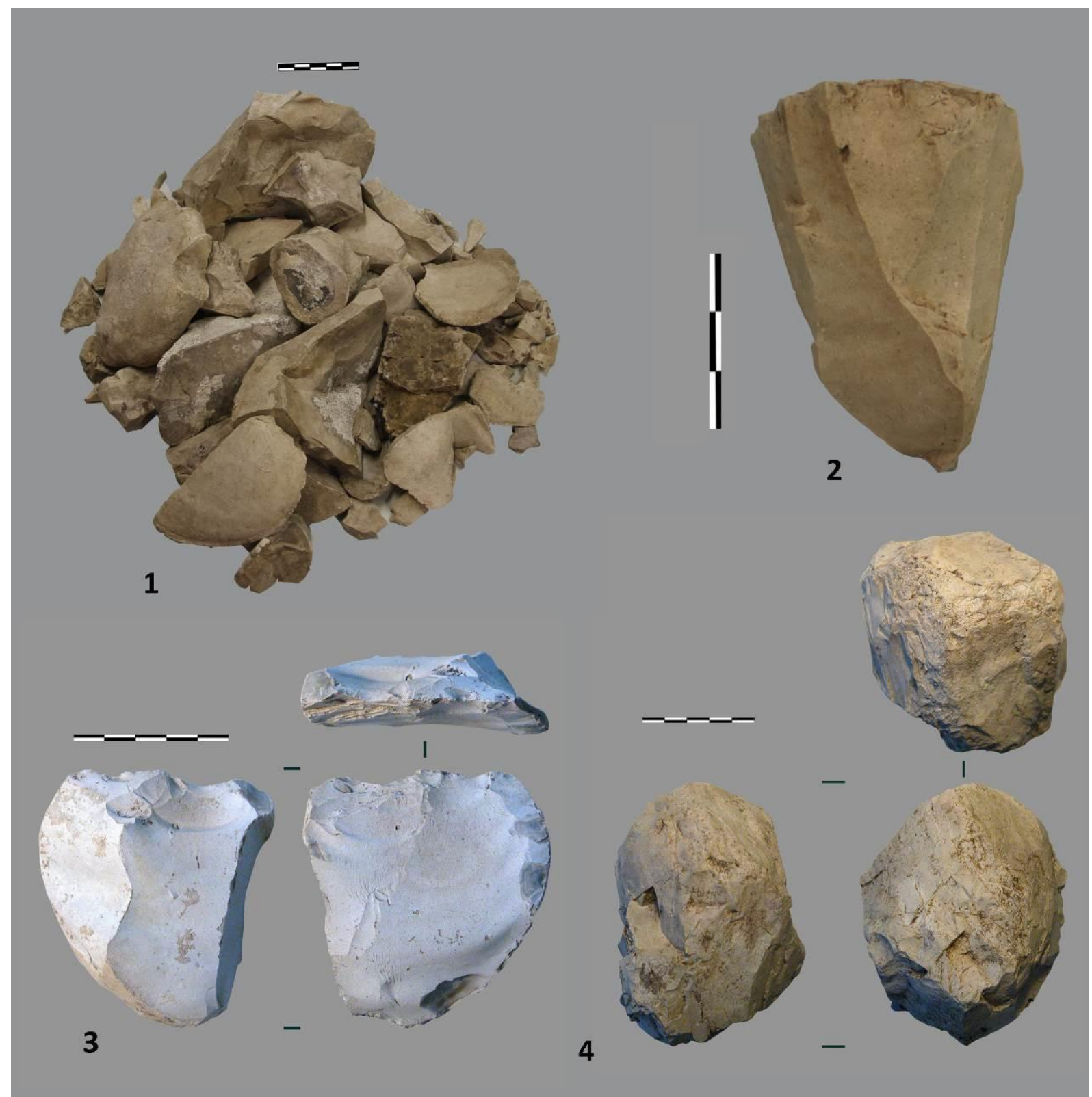

Figure 15. Photograph showing 1) the diversity of lithic material and products of large size and with cortex. 2) Pyramidal core. 3) A wedge - a retouched product that is related with the mining activity of nodules extraction. 4) A core turned into a hammer.

The cores present varied morphologies and formats - well shaped blade technology cores with percussion and flaking platforms, or cores with platforms randomly arranged and with 
different shapes. There are also natural cores with one or two flake removals, for testing the flint quality (Figure 15.2).

The retouched material is made up of notched and denticulated flakes and blades with the same characteristics as the débitage products mentioned above. Projectile points, end scrapers and side scrapers in standard forms were also collected. They are smaller than the other lithic remains and they resemble the typical lithic industries of other archaeological sites of the same age (Figure 15.3). The cores of knappable material with profuse percussion marks are identified as a consequence of their reutilisation as hammers (Figure 15.4).

Finally, apart from the flint artefacts, there are quarrying tools and remains of ophite (dolerite). For example, there are flakes and a block employed as a hammerstone with a roundness to its edges because of the impacts (Figure 16.1). The artefact most representative of the mining industry is a bevelled antler, similar to those discovered at other mining sites and described as a pick (Boguszewski \& Lozny 2011) (Figure 16.2).

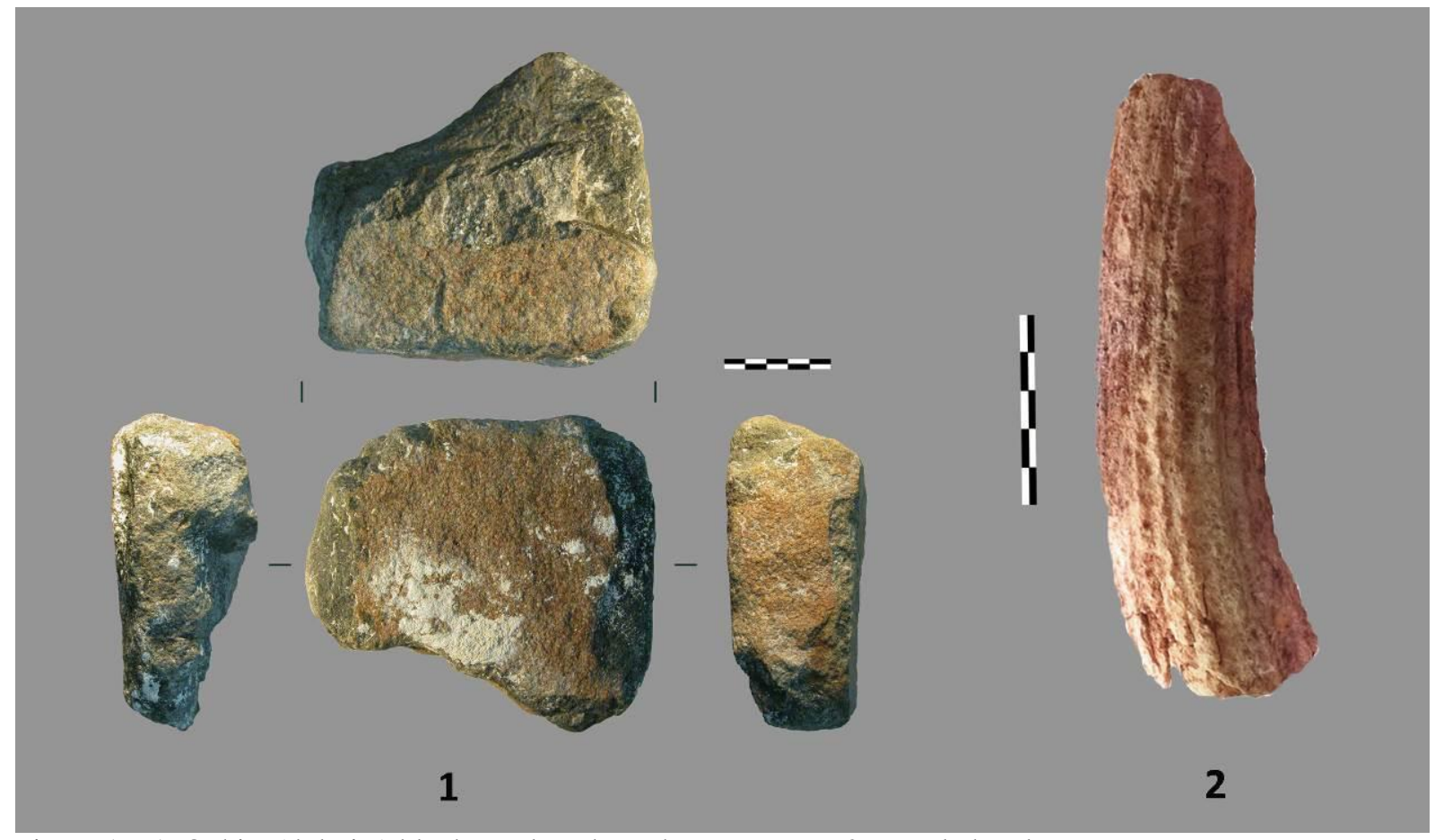

Figure 16. 1. Ophite (dolerite) block employed as a hammerstone. 2. Beveled antler.

\section{The flint of Araico and its archaeological context during the Neolithic}

During the last decade, in the Basque Country, multiple raw material analyses of the lithic industries have been developed. They evidence the relevance of the utilisation of Treviño flint throughout the Prehistory and define it as one of the main four "Lithological Tracers" that exist in the Cantabrian-Pyrenean area (together with 'Urbasa flint', 'Chalosse flint' and 'Flysch flint').

Many of the studies relating to flint sources focus on the Upper Palaeolithic period. These works confirm that Treviño flint is a "long-distance Tracer", since it is distributed all along the Cantabrian coast from Las Caldas site (Asturias, Spain) to Brassempouy (Landes, France); covering a distance of more than 500 kilometres (Corchón et al. 2009). In the same way, this type of flint was used during the Mesolithic in the region (Tarriño 2001; Cava et al. 2007-2008).

The excavation of the crescent-shaped dump, presented in this work, permitted the dating of organic materials using C14-AMS. All the dates, including the ones from the bibliography, 
have been calibrated BC 2 sigma using the OxCal 4.2 program (Bronk Ramsey 2009). Concretely, a deer antler was dated: $4542-4371$ cal. BC 2 sigma and a piece of charcoal (Quercus Robur sp.): 5056-4830 cal. BC 2 sigma. The two dates match the Middle Neolithic (base of the Middle Neolithic period in the Basque-Country) (Fernández-Eraso el al. in press; Tarriño et al. 2011b). Studies that differentiate Treviño flint varieties in the surrounding Neolithic sites are still not developed; only the generic type has been determined. This information would be interesting if it is compared with the variety extracted from each of the mining structures. In earlier dates than the ones of Araico, this flint appears in the level I of Mendandia site (Álava) (5479-5331 cal. BC 2 sigma) located at a distance of 14 kilometres from the mine (Tarriño 2006). Farther away, in "Sierra de Cantabria", but with similar chronologies, it has been certified Treviño flint: in the upper level IV (4974-4452 cal. BC 2 sigma) and level IV (5530-4550 cal. BC 2 sigma) of Peña Larga site (Álava), as well as in level XV (4599-4347 cal. BC 2 sigma, 4799-4517 cal. BC 2 sigma, 5225-4854 cal. BC 2 sigma) and level XVI (5326-5030 cal. BC 2 sigma) of Los Husos I (Álava) (Fernández-Eraso et al. 2005). For this period the presence of this raw material has been proved in further areas as the coast of Biscay, it is the case of Pico Ramos site where Treviño flint appears. Pico Ramos presents the following radiocarbon dates: 4331-4057 cal. BC 2 sigma, 4897-4547 cal. BC 2 sigma and 5210-4729 cal. BC 2 sigma (Zapata 1995; Tarriño 2003).

As we have already explained, the mining evidences along "Sierra de Araico" are innumerable. So it might be possible that the flint exploitation might have continued during the recent Prehistory. In fact, in the late Neolithic and the Chalcolithic there are multiple evidences of Treviño flint presence, as in archaeological sites close to the mine - Kanpanoste Goikoa case (Álava) — (Tarriño 1998), as in others further - Arenaza I and Picos Ramos (Bizkaia) - (Tarriño 2003) or in megalithic architecture distributed all along the Basque Country (Tarriño \& Mujika 2004; Tarriño et al. 2009).

\section{Conclusions}

The lacustrine-palustrine carbonated outcrops of Treviño ("Sierra de Araico - Montes de Cucho and Busto") are one of the most important silicifications that have been exploited since Prehistoric times in the Western Pyrenees.

One of the varieties of nodular flint is identified and also their exploitations. They have generated mining evidences as vast dumps and trenches with dimensions of thousands of metres long which follow the silicificated geological layers. They are nodular flints in dark colour (high quantity of organic matter), of good purity (few carbonated content as impurities), thin grain (microcrystalline and cryptocrystalline), homogeneous (without clefts or interior structures that condition the fracture) and with a very thin cortex (micrometric thickness that favours the flint to drop easily from the calcareous host rock).

We have identified three types of mining structures along the excavation sector: trenches, linear dumps and crescent-shaped dumps. The excavation was carried out on the mining area previously mentioned, that is a filling structure forming a little depression of $20-30 \mathrm{~m}$ diameter. In this way, the layer of flint, in its original position, would outcrop many metres uphill and the exploitations might had advanced until the height reached by the exploitation front might made unviable the flint extraction. In addition, it has been detected that the slag heap overflows on the original mountainside 10-12 metres downhill, drawing the typical crescent-shaped form that is presented in this type of dump developed on mountainsides (Figure 17). 


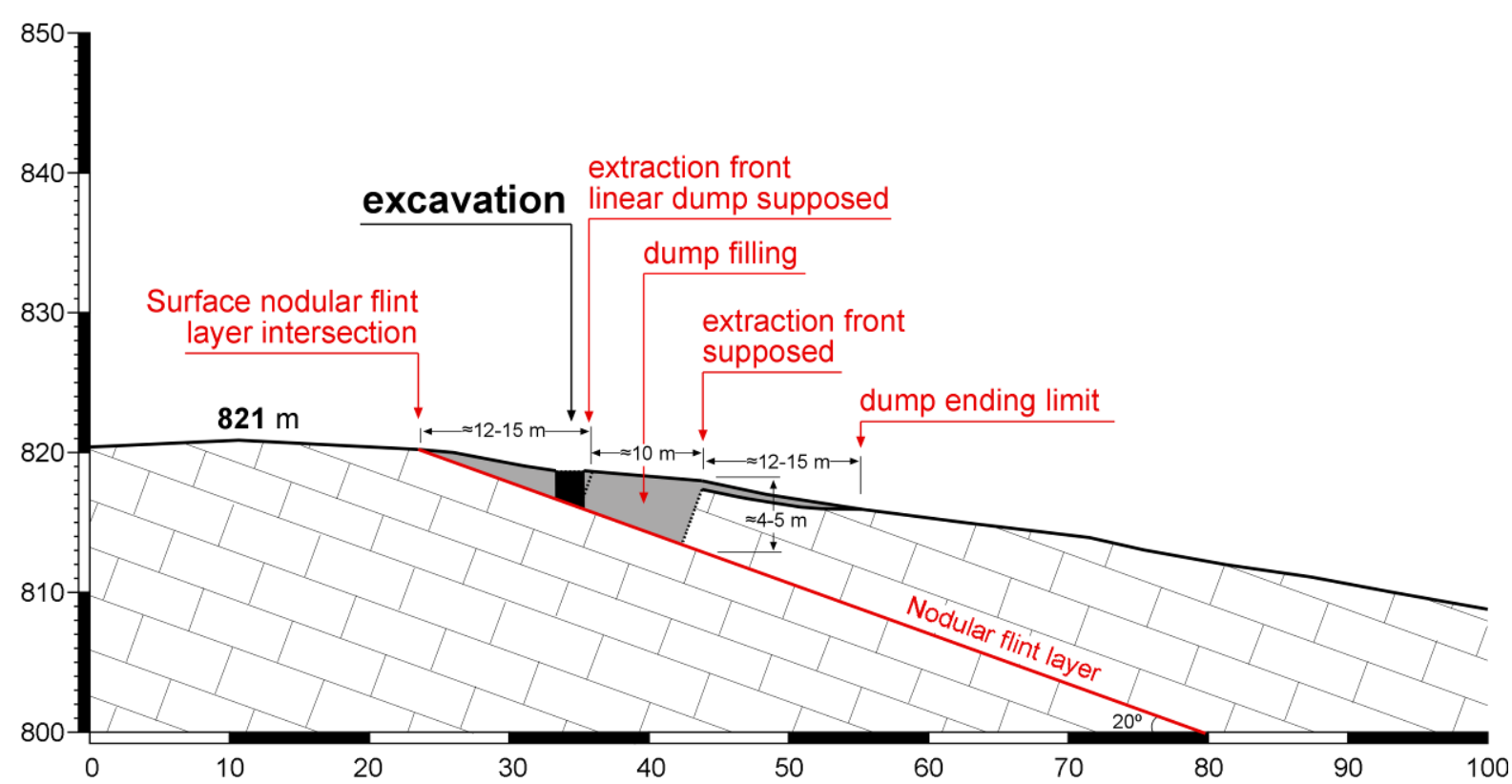

Figure 17. Cross-section of the excavated crescent-shaped dump allows interpreting the mining structure. The layer of flint might crop out many metres uphill and the exploitation have advanced till the height reached by the extraction front might make impossible its acquisition.

The dating made on a charcoal fragment (Quercus robur sp) and a piece of deer antler revealed an antiquity ca. $5000 \mathrm{cal}$. BC. The dates fit in with the Middle Neolithic of the chronological sequence for the Basque Neolithic period. At present, the gathered data are not clarifying to understand who the people that exploited the mines were and their socioeconomic behaviours derived from this activity. However, we know the existence of a Neolithic and Chalcolithic settlement of La Renke in the Rojo River, which is located in the south of "Sierra de Araico" (Lobo-Urrutia 1997). In the same way, in the field surveys carried out by Estavillo and later by the Rojo River survey team, there were found numerous remains that proved other settlements in the area. Therefore we consider the possibility that these places were directly related to the exploitation and control of the flint mining. Nevertheless, this is one of the principal hypotheses that must be corroborated as long as the investigation progresses. Additionally, the obtained dates fit in with the approaches which explain the neolithization process from the Ebro Basin (Fernández-Eraso 2008).

In a quantitative level, the huge amount of débitage products and natural chunks opposite to the retouched products, cores and core sharpening. Almost the totality of the products presents cortex. The flint nodules with marks have the same morphological and volumetric characteristics, what we interpret as a testing to check their quality and possibilities.

In a qualitative level we noticed various groups; tools for the mining exploitation, hammers and percussors, picks and wedges. Another set standardised and with common characteristics of any prehistoric context, as scrapers, end scrapers, denticulates, etc. And finally a group of artefacts that are out of the typological classifications that we can interpret as fortune tools, where hard formats are searched and with double-face laterals for performing some work, possibly a mining work.

Furthermore, the mining exploitation forms have been confirmed and defined, specifically those structures which were assumed from the information of surface materials. The excavation revealed an intensive open-air exploitation that is developed longitudinally. This exploitation method is determined by the Geology that does not allow the construction of 
underground galleries. That is why the flint nodules extraction is developed along the unconsolidated lacustrine-palustrine limestones.

Finally mention that the prehistoric mining structures of Treviño that have been described are an exceptional mining complex for the Iberian Peninsula. The most complete information about mining exploitation is the work of Casa Montero (Madrid), dated ca. 5000 cal. BC (Díaz-del-Río \& Consuegra 2011). However, the flint exploitation techniques and structures are different in both cases, although they have similar chronology. This is why it is necessary to go in depth into Treviño mines knowledge: i) Delimitation of the mining complex, one of the most extensive of Europe discovered till the moment with more than $2,000 \mathrm{Ha}$; ii) Continue the identification of new mining exploitation structures by excavations and field surveys; iii) Track flint in prehistoric sites (Palaeolithic, Mesolithic, Neolithic and Chalcolithic) and in an interregional perspective; iv) Continue the characterization of new varieties of Treviño flint; and v) Definitely, understand the socio-economic impact of the exploitation in the prehistoric societies.

It should be noted that the file for declaration of Asset of Cultural Interest ("Bien de Interés Cultural, BIC") is being processed at the moment by the Autonomous Community of Castilla y León.

\section{Acknowledgements}

This work is part of the work of the "Grupo Consolidado de Investigación en Prehistoria (IT-622-13) Área de Prehistoria, Dpto de Geografía, Prehistoria y Arqueología (UPV/EHU) ". In the same way it has been possible thanks to the project: HAR2011-26956 of the "Ministerio de Economia y Competitividad (MINECO)". One of us (A.S.) is recipient of the Pre-Doctoral Fellowship of the Basque Government. Lastly we want to thanks the reviewers for their constructive corrections.

\section{References}

Benito-Calvo, A., Tarriño, A., Lobo P.J., Junguitu, I. \& Larreina, D. 2010, Geomorphology and prehistoric flint mining evidence in the Sierra de Araico (Basque-Cantabrian Basin), Burgos-Álava, Spain. Journal of Maps, 6(1): 584-590. doi:10.4113/jom.2010.1147

Boguszewski, A. \& Lozny, L.R. 2011, Antlers in Flint mining: technological opportunism and symbolism. In: Le concept de territoires dans le Paléolithique supérieur européen, (Djindjian, F., Kozlowski, J., \& Bicho, N., Eds.), BAR International Series Vol. 1938, Archaeopress, Oxford: p. 129-137.

Bronk Ramsey, C. 2009, Bayesian analysis of radiocarbon dates. Radiocarbon, 51(1): 337360.

Cava, A., Alday, A. \& Tarriño, A. 2007-2008, La circulación de materias primas líticas en la transición Mesolítico/Neolítico antiguo en el País Vasco. Los abrigos de Mendandia, Kanpanoste y Aizpea. Veleia, 24-25: 581-609. (in Spanish) ("Raw lithic material circulation in the Mesolithic/Ancient Neolithic transition in the Basque Country. The shelters of Mendandia, Kanpanoste and Aizpea")

Corchón, M.S., Tarriño, A. \& Martínez, X. 2009. Mobilité, territoires et relations culturelles au début du Magdalénien moyen cantabrique: nouvelles perspectives. In: Le concept de territoires dans le Paléolithique supérieur européen, (Djindjian, F., Kozlowski, J., \& Bicho, N., Eds.), BAR International Series 1938, Archaeopress, Oxford: p. 217-230. (in 
French) ("Mobility, territories and cultural relations at the beginning of the Middle Cantabrian Magdalenian: new perspectives")

Díaz-del-Río, P. \& Consuegra, S. 2011, Time for action. The chronology of mining events at Casa Montero (Madrid, Spain). In: Proceedings of the 2nd International Conference of the UISPP Commission on Flint Mining in Pre- and Protohistoric Times, 14-17 october, 2009 Madrid, (Capote, M., Consuegra, S., Díaz-del-Río, P. \& Terradas, X., Eds.), BAR International Series 2260, Archaeopress, Oxford: p. 221-229.

Estavillo, D. 1955, Las industrias líticas de Araico (Condado de Treviño). Zephyrus, 6: 172177. (in Spanish) ("The lithic industries of Araico (Treviño County)")

Fernández-Eraso, J. 2008, La secuencia del Neolítico en La Rioja Alavesa desde su origen hasta las primeras edades del metal. Veleia, 24-25: 669-688. (in Spanish) ("The Neolithic sequence in La Rioja Alavesa from its origin to the first metal ages")

Fernández-Eraso, J., Mujika, J. A., \& Tarriño, A. 2005, Relaciones entre la Cornisa Cantábrica y el valle del Ebro durante los inicios del Neolítico en el País Vasco. In: Actas del III Congreso del Neolítico en la Península Ibérica, (Ontañón Peredo, R., García-Moncó Piñeiro, \& Arias Cabal, P. Eds.), Santander: p. 201-210. (in Spanish) ("Relations between the Cantabrian Coast and the Ebro Valley during the beginning of the Neolithic in the Basque-Country")

Fernández-Eraso, J., Mujika, J.A., Zapata, L., Iriarte, M. J., Polo-Díaz, A., Castaños, P., Tarriño, A., Sesma, J. \& García-Gazólaz, J. in press, The introduction, development and consolidation of the economy of production in the Basque Region. Quaternary International, vol. "Western Pyrenean Region Quaternary"

IGME, 1978, Mapa Geológico de España, 1/50.000. Hoja núm. 138 - La Puebla de Arganzón, Ministerio de Industria y Energía, Madrid. 44 p. (in Spanish) ("Geologic Map of Spain, 1/50.000. Map no. 138 (La Puebla de Arganzón)")

Lobo-Urrutia, P.J. 1997, Ensayo de aplicación teórica de la Estratigrafía Analítica a los yacimientos al aire libre post-paleolíticos. El asentamiento de La Renke-N (SanturdeMijancas, Álava). Krei, 2: 45-67. (in Spanish) ("Theoretical application test of the Analytical Stratigraphy to the open-air post-Palaeolithic sites. The La Renke-N settlement (Santurde-Mijancas, Álava)")

Luedtke, B.E. 1992, An Archaeologist's Guide to Chert and Flint; a handbook. Archaeological research tools Vol. 7. Institute of Archaeology, University of California, Los Angeles, $172 \mathrm{p}$.

Orue, I. 2013, Fotointerpretación y teledetección como herramienta para la localización de estructuras mineras prehistóricas en la Sierra de Araico (Burgos-Araba). CKQ Estudios de Cuaternario / Kuaternario Ikasketak / Quaternary Studies, 3: 77-90. (in Spanish) ("Photo-interpretation and Remote Sensing as tool for locating prehistoric mining structures in the Sierra of Araico (Burgos-Araba)")

Ortiz, L., Vivanco, L., Ferreira, J.J., Lobo, P.J., Muñoz, M.D., Pinillos, R., Tarriño, J.M. \& Tarriño, A. 1990, El hábitat en la prehistoria del valle del Río Rojo (Álava). Cuadernos de Sección de Eusko-Ikaskuntza (Prehistoria-Arqueología), 3: 1-315. (in Spanish) ("The habitat in the Prehistory of the Rojo River Valley (Álava)")

Ramírez del Pozo, J. 1973, Síntesis geológica de la provincia de Álava. Obra Cultural de la Caja de Ahorros Municipal de la Ciudad de Vitoria, Vitoria, 66 p. (in Spanish) ("Geological synthesis of Alava province") 
Tarriño, A. 1998, Análisis de los restos líticos silíceos del yacimiento arqueológico de Kanpanoste Goikoa. In: Memorias de yacimientos alaveses. Vol. 5. Kanpanoste Goikoa (Virgala, Álava), (Alday, A., Ed.), Diputación Foral de Álava, Vitoria: 105-107. (in Spanish) ("Analysis of the siliceous lithic remains of the archaeological site of Kanpanoste Goikoa")

Tarriño, A. 2001, El sílex en la cuenca vasco cantábrica y pirineo navarro: caracterización y su aprovechamiento en la Prehistoria. PhD Thesis, Universidad del País Vasco/Euskal Herriko Unibertsitatea, Bilbao, 365 p. (in Spanish) ("The Flint in the Basque-Cantabrian Basin and the Navarre Pyrenees: characterization and exploitation in Prehistory")

Tarriño, A. 2003, La piedra como materia prima en la Prehistoria. In: Ekin harriari: historiaurreko tresnak. Manos a la piedra: las herramientas de la prehistoria, Museo Arqueológico, Etnográfico e Histórico Vasco, Bilbao: p. 17-30. (in Spanish) ("The Stone as raw material in Prehistory")

Tarriño, A. 2006, Fuentes de aprovisionamiento de los sílex del yacimiento arqueológico de Mendandia (Sáseta, condado de Treviño). In: El legado arqueológico de Mendandia: Los modos de vida de los últimos cazadores en la Prehistoria de Treviño. (Alday, A., Ed.), Junta de Castilla y León, 15: 473-480. (in Spanish) ("Supply sources of the flints of the archaeological site of Mendandia (Sáseta, Treviño County)”)

Tarriño, A. \& Mujika, J.A. 2004, La gestión del sílex como uno de los elementos articuladores del territorio en el megalitismo vasco. Kobie, 6(1): 191-202. (in Spanish) ("Flint management as a territorial element in the basque megalithics")

Tarriño, A., Mujika, J.A. \& Aguirre, M. 2009, Las grandes láminas en el mundo funerario del País Vasco: Contexto cultural, tecnología y materias primas. In: Les grans fulles de sílex. Europa al final de la Prehistòria. Actes (Gibaja, J.F., Terradas, X., Palomo, A. \& Clop, X., Eds.) Monografies Vol. 13, Museu d'Arqueologia de Catalunya, Barcelona: p. 113-118. (in Spanish) ("The large blades in the funerary world of the Basque-Country: cultural context, technology and raw material")

Tarriño, A., Benito-Calvo, A., Lobo, P.J., Junguitu, I. \& Larreina, D. 2011a, Evidence of Flint mining in the Treviño syncline (Basque-Cantabrian Basin, Western Pyrenees, Spain) In: Proceedings of the 2nd International Conference of the UISPP Commission on Flint Mining in Pre- and Protohistoric Times, 14-17 October, 2009 Madrid, (Capote, M., Consuegra, S., Díaz-del-Río, P. \& Terradas, X., Eds.), BAR International Series Vol. 2260, Archaeopress, Oxford: p. 171-182.

Tarriño, A., Lobo, P.J., García-Rojas, M., Elorrieta, I., Orue, I., Benito-Calvo, A. \& Karampaglidis, T. 2011b, Introducción al estudio de las minas neolíticas de sílex de la sierra de Araico (Condado de Treviño). Campaña de excavación del 2011. Estudios de Arqueología Alavesa, 27: 7-48. (in Spanish) ("Introduction to the study of "Sierra de Araico" Neolithic Flint Mines (Treviño County). Excavation campaing of 2011")

Zapata, L. 1995, La excavación del depósito sepulcral calcolítico de la cueva Pico Ramos (Muskiz, Bizkaia). La industria ósea y los elementos de adorno. Munibe, 47: 35-90. (in Spanish) ("The excavation of the burial cave Pico Ramos (Muskiz, Biscay). The ornamental and bone industry") 